\title{
Forecasting of Government Yield Curve in Post-Corona Pandemic
}

\author{
Vera Mita Nia* \\ Economic Department, Pakuan University, Indonesia \\ e-mail: vera@unpak.ac.id \\ Hamzah \\ Economic Department, Pakuan University, Indonesia \\ e-mail: hbst007@gmail.com
}

\begin{abstract}
The Indonesia government conducts several fiscal strategies to solve Revenue and Expenditure Budget (APBN)'s deficit due to corona pandemic by relaxation of APBN's deficit policy, using surplus balance, upsizing loan and bond in domestic and valas currency. Upsizing or issuance a new Indonesian bon called SUN, would increase cost of rate is paid by government and its maturity that impacted to yield curve and risk of SUN. It has inspired this research to (1) investigate the determinant of yield curve due to shocks that occur in Indonesian macroeconomic during the pandemic (2) the impact of the pandemic on SUN's risk and (3) the forecast of the yield curve in SUN after the pandemic using the VAR / VECM method. The reasearch used secondary data of bond yield from Indonesian Stock Market and imposed the effect of such as inflation, BI Rate, Kurs and foreign exchange that is taken from several sources such as BPS, Central Bank of Indonesia and Bloomberg during 2015 January until 2020 May. This research proves that the five main macroeconomic indicators have an influence in the short and long term on the yield curve. YIELD, GDP and BIR variables have a significant negative effect in the short term on the yield curve, whereas CPI, KURS and CD have no significant effect. The ECT's coefficient shows the speed of adjustment towards the long-term balance and the BI Rate adjustment is faster than other variables with an ECT coefficient of 0,33 . The estimation results show that the average R-squared is above 55 percent with the highest value of 79,35 percent, this indicates that the equation was formed because the research variables amounted to the R-squared results.
\end{abstract}

Keyword: Yied Curve, bond, forecasting, corona, risk. 


\section{INTRODUCTION}

Macroeconomic conditions in early 2020 were haunted by the corona virus pandemic that swept the world. The virus which allegedly appeared in Wuhan, China on December 8, 2019 has caused global economic shocks. Anticipation of the spread of viruses such as quarantine and physical distancing carried out by a number of countries including Indonesia. It has resulted in decreased demand in various sectors, especially exports, imports, tourism and investment. Indonesia was only able to achieve economic growth of 2,97 percent (yoy) in Q1 of 2020, it's mean 4,97 percent lower (yoy) compared to Q1 2019. The government even predicted that economic growth in 2020 would only be $-0,4$ percent -1 percent and the state budget deficit of 5,07 percent in the worst scenario.

In Q1 2020, the APBN deficit reached Rp. 74,47 trillion or $-0,44$ percent as a result of the additional state expenditure to handle the pandemic. Some fiscal policies have been implemented to overcome this, including relaxation the State Budget deficit policy, using surplus balance (SAL), and upsizing loan and bond in domestic and valas currency. The government has issued new global bonds with a total value of approximately US \$20 billion or equivalent to 320 trillion rupiah to mitigate the impact of the pandemic. SUN timed 10,5 - 50 years with coupon average 7,342 percent. It higher than 10y SUN's coupon before pandemic.

Investors consider that SUN is having smaller risk compared to others investment. According Che-Yahya et al. (2016); Chen (2010); Rahardjo (2004) higher maturity bonds will provide a higher yield as compensation but it has lower bond prices. SUN over the past five years has given higher yield to high-maturity bonds and formed a positive yield curve, as shown in table 1 below:

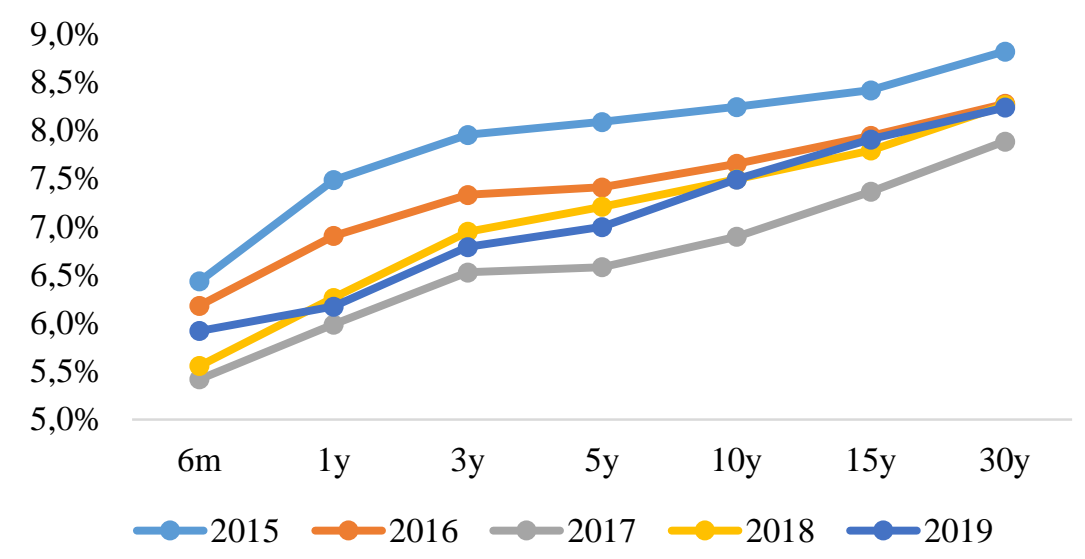

Figure 1. Government Bond Yield Curve in 2015 - 2019

Source: LKPP (2014-2019) (data processed)

Yield curve forecasting is used by investors to forecast interest rates, set bond prices and strategies to increase their profits. For the government, the curve is used to determine interest rate policy, inflation targeting and long-term economic growth. They must calculate carefully so that its fiscal policy is able to maintain monetary stability while getting a cheap cost of funds using bond in this pandemic situation.

Yield bonds are the main contributor to the yield curve movement (Sihombing et al., 2013). The effect of macroeconomic shocks will affect the SUN's yield curve which will have an impact on bond prices and investors' investment decisions, has investigated by many research. Jaramillo \& Weber (2012) Show that long-term yield in Indonesia and other developing countries, are strongly influenced by investor expectations of macroeconomic indicators, country fundamentals and liquidity. According Sundoro (2018) inflation and economic growth are two factors that affect yield bonds. The Consumer Price Index (CPI) as proxy of inflation has used to measures the average price of goods and services consumed by households. While Gross Domestic Product (GDP) is an indicator of a country's economic 
growth measured base on increasing in the production capacity of goods and services significantly in a certain period of time. Research Orlowski and Kirsten (2005); Adonso et al. (2010); Rahman et al. (2013); Hsing (2015) also support the statement of the positive relationship between these two factors on yield. However, different results were stated by Muharam (2011); Perovic (2015) who stated the negative relationship between the two factors on yield.

Exchange rate is another factor that infuencing yield Gadanecz (2014) states that the exchange rate and the larger yield influence investors' decisions to hold state bonds in local currencies. The weakening of the rupiah against the US dollar encourages the provision of high interest rates to attract investment, the impact of which is the decline in bond prices on the secondary market. The same results were stated by Jaramillo and Weber (2012), Sihombing et al. (2013); Sundoro (2018); Wibisono (2010); but Yu Hsing (2015) stated the opposite. The interest rate indicated by the BI Rate is also one of the determinants of the government yoeld bond. The reciprocal relationship between interest rates and bond prices is commonly referred to as market interest rate risk. Malkiels's bond theory as described in Bodie et al. (2006) explains a significant negative relationship between the two. If bond prices increase the rate of return will decrease, and vice verse. Research of Jaramillo and Weber (2012); Sihombing et al. (2013); and Sundoro (2018) produce conclusions that are in line with the theory, but Budina and Mantchev (2000) found a negative relationship.

Default risk is another risk factor that is considered by investors in investing in bonds. The country's ability to repay and on time payment is reflected in the liquidity ratio and the amount of the country's foreign exchange reserves is an indicator of that ratio. Muharam (2011) explains that the liquidity crisis is the government bonds's default risk of default on, which is reflected in the country's foreign exchange reserves. Government liquidity indicated by the country's foreign exchange reserves is another macroeconomic factor that has a significant relationship with YIELD according to Budina and Mantchev (2000); Jacobs et al. (2011); Jaramillo \& Weber (2012); Sihombing et al. (2013); Baldacci et al. (2008); and Idham (2014).

It has inspired this research to (1) investigate the determinant of yield curve due to shocks that occur in Indonesian macroeconomic during the pandemic (2) the impact of the pandemic on SUN's risk and (3) the forecast of the yield curve in SUN after the pandemic using the VAR / VECM method. The purpose of this research (1) to determine the impact of the corona virus pandemic on yield provided by the government, (2) as an indicator for the government in managing yield against the risks that must be faced so that government interest expenses remain at a reasonable and controlled level, (3) provide insight of feasibility of SUN in the future to investors.

\section{Literature Review Yield}

Yield bonds consist of changes in the capital gains and coupons that are given constantly based on a predetermined payment period (Rose et al., 2010). A declining yield indicates low investment risk in bonds, thereby increasing bond prices, and vice versa. Fabozzi (2010) stated that investors must know the determinant yield, such maturity, nominal value, coupon and market interest rates before investing in bonds with the same characteristics and periods. Research conducted comprehensively supports these statements, Fabozzi (2000); Che-Yahya (2016); Chen (2011); and Rahardjo (2004) who argue that maturity will affect yield and bond prices. The higher the maturity is causing higher yield, but the price will decrease. High bond liquidity is an attraction for investors who will increase bond prices but on the other hand decrease yield.

Macroeconomic factors such as GDP growth, inflation growth rates and interest rates countries (Tandelilin, 2010). The relationship between macroeconomic factors and government yield bonds has also been investigated by several researchers including Jurksas and Kropiene (2014) who stated that interest rates and money supply significantly affect the security price of 
Lithuanian government bonds. However, the effects of GDP and foreign direct investment were found to be statistically insignificant. Gadanecz et al., (2014) states that investors' decisions to hold state bonds in local currencies influence by the exchange rates and yield. Whereas research by Miyajima et al. (2012) found that domestic yield sun in developing countries is influenced predominantly by US Treasury yields. Yield of Indonesian government bonds for short-term, medium-term and long-term tenors will fluctuate due to all the variables contained in the macroeconomic factors of inflation such as money supply and CSPI and BI Rate (Sundoro, 2018).

\section{Yield Curve}

According to Sihombing et al. (2013) the yield curve is estimated by applying the time structure method that forms bonds that have coupons with different maturity dates. Diebold and $\mathrm{Li}$ (2006) explain that the yield curve is identified into three factors called slopes that represent short-term interest rates, then curvatures that represent medium-term interest rates, and levels that represent long-term interest rates. Fabozzi (2005) describes the shape of the yield curve into three, namely the inverted yield curve, the flat yield curve and the positive yield curve. Investors prefer a positive curve that shows that bonds with high maturity will get more returns as compensation. Positive curve is a good indicator of economic growth characterized by an increase in inflation so that demand for future returns will be higher. While negative curves are interpreted as opposites so investors will be willing to take risks by accepting lower yields on high-maturity bonds.

\section{RESEARCH METHODS}

\section{Data collection}

The data used in this research are secondary data based on time periods (time-series) that conducted from January 2015 until March 2020. The frequency of data is monthly data so that the total amount of data is 390 data sourced from :

Table 1. Variables and Sources of Research Data

\begin{tabular}{lcccc}
\hline \multicolumn{1}{c}{ Variable } & Symbol & Source & Unit & Period \\
\hline Inflation & CPI & BPS & Percent & Monthly \\
Economic growth & GDP & BPS & Percent & Monthly \\
BI Rate & BIR & Bank Indonesia & Percent & Monthly \\
Exchange rate & KURS & Bank Indonesia & Logaritma & Monthly \\
Foreign exchange reserves & CD & Bank Indonesia & Nominal & Monthly \\
YIELD Government Bonds & Y & Bloomberg & Percent & Monthly \\
\hline
\end{tabular}

Source: Combined several sources (2015 - 2020)

\section{Analysis Tool}

Many studies state that the YIELD curve is formed by the yield itself and macroeconomic factors which are generally time series. This research will test these factors using the econometrics model follows the research use the Vector Error Correction Model (VECM) approach Sihombing (2013) and Sundoro (2018) which is a form of vector Autoregressive (VAR) that is distracted and data is processed using Eviews 9 application. Figure 2 is represented the analaysis tools that used in this research. 


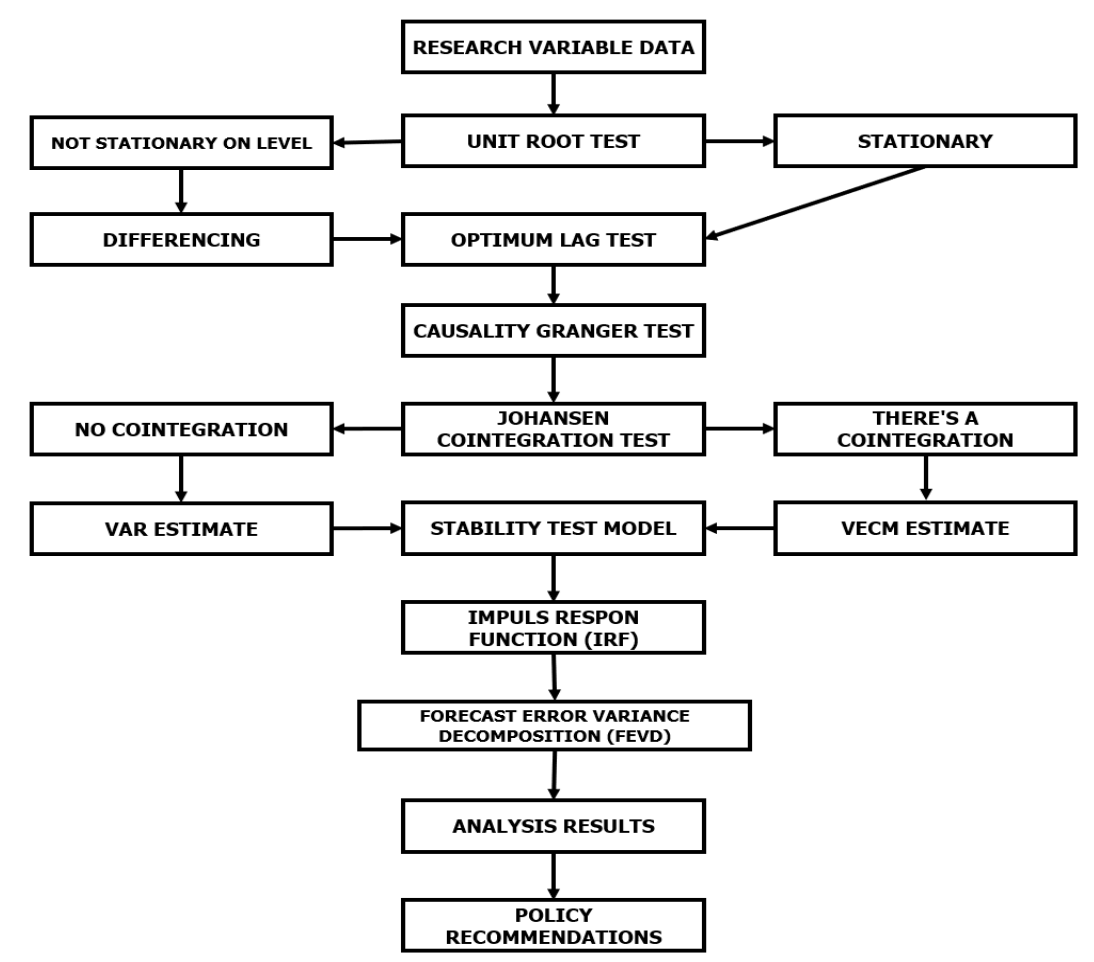

Figure 2. Variables and Sources of Research Data Source: Researcher (Data Processed)

VAR / VECM analysis techniques are applied because they have the ability to provide analytical tools such as:

1. Impulse Response Function (IRF) is used to determine how long the effect of shocks from one variable to the other variable occurs.

2. Forecast Error Variance Decomposition (FEVD) which is used to estimate the percentage contribution of each variable to the change in a particular variable.

3. Granger Causality Test is used to determine the causal relationship between variables.

4. Forecasting is used to extrapolate current values and future values of all variables by utilizing all past information from these variables.

\section{Empirical Model}

The Vector Autoregressive (VAR) method shows that each variable is a linear function of a constant and its lag value depends on the lag value of other variables. According to Widarjono (2013) , the VAR model in general with $\mathrm{t}$ variables is written as follows :

$$
Y_{j t}=\beta_{j}+\sum_{=1}^{p} \gamma_{j i} Y_{1, t-i}+\sum_{=1}^{p} \theta_{j i} Y_{1, t-i}+\cdots+\sum_{=1}^{p} \lambda_{T i} Y_{T, t-P}+e_{j t}
$$

$Y_{j t}$ is considered as a forecast number for the variable $\mathrm{j}$ at the time $\mathrm{t}$, while $\mathrm{T}$ indicates the number of variables with $\mathrm{i}$ is $1,2, \ldots .$. up to $\mathrm{T}$. The constant for the variable $\mathrm{j}$ is symbolized by $\beta_{j}$ and $\mathrm{P}$ is the lag or number of lags with the value $\mathrm{i}$ is $1,2, \ldots .$. to $\mathrm{P}$. The I inaction in variable 1 is given a parameter value with the notation $\gamma_{j i}$ while in variable 2 in the lag in the same level the parameter value is given with the notation $\theta_{j i}$ nd so on until $\lambda_{T i}$ which shows the parameter value in the $\mathrm{T}$ variable with lags at the I level. The residual value in this model is represented by $e_{j t}$.

In general, the VECM empirical model used in this research refers to Verbeek (2000)

$$
\Delta Y_{t}=\sum_{i-1}^{k-1} \tau_{t} \Delta Y_{t-1}-\gamma \beta Y_{t-1}+\varepsilon_{t} .
$$


Explanation:

$\tau=$ coefficient of short-term relationships

$\beta=$ coefficient of a long-term relationship

$\gamma=$ speed to balance (speed of adjustment)

$Y_{t}=$ endogenous variables used in the model

\section{RESULTS AND DISCUSSION}

\section{Descriptive Analysis}

Descriptive analysis is used to provide an overview of research data during the observation period. The results obtained are time series plots as shown in the Figure 3 below:

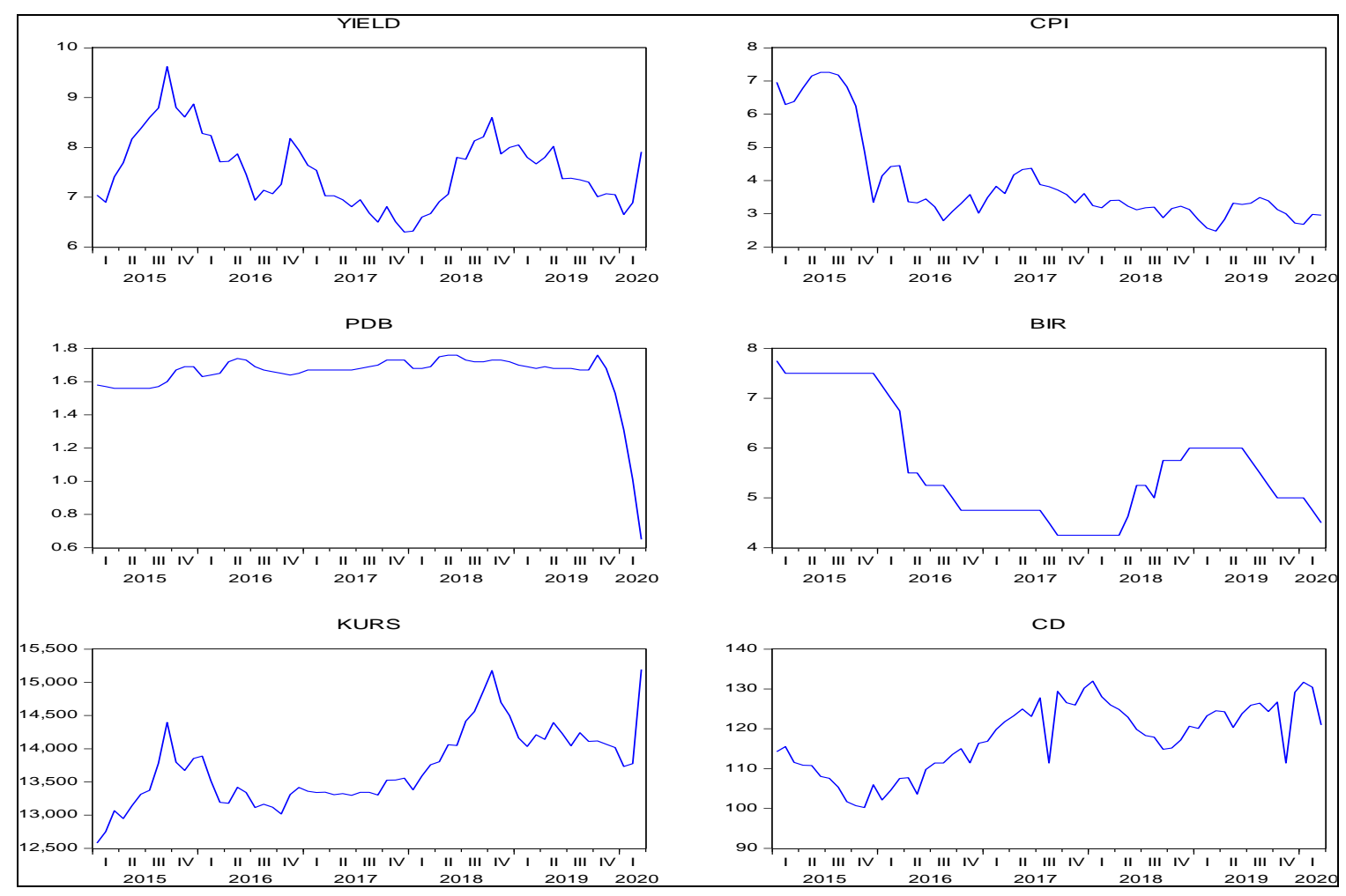

Figure 3. Descriptive Analysis

Source: Data Processed Through Eviews

Figure 3 has shown descriptive analysis and trends on all research variables. YIELD, CPI and BIR variables have a downward trend, while the exchange rate and foreign exchange variables reverse. The YIELD variable during the observation period experienced the highest value in September 2015 and the lowest point in December 2017. The corona pandemic has increased YIELD so that in March 2020 the Figure 3 shows upward movement, although it has not equaled the highest point. Macro conducive conditions cause investors to be afraid to invest, the government is trying to increase the yield on bonds to attract funds. At the same time, the BIR variable has decreased, this will further strengthen investors to choose other investment alternatives that provide higher returns such as bonds. The drastic increase during the pandemic was also experienced by the KURS variable, this was due to the high dollar purchase as an anticipatory measure for investors facing the crisis. The Government through Bank Indonesia has intervened to stabilize the value of the rupiah in the spot market, secondary market and forward market, but until now the rupiah exchange rate has remained in the range of Rp. $15.000,00$. Intervention actions are enough to drain the country's foreign exchange reserves to reach Rp. 300 trillion rupiah. This is in line with the CD chart that plummeted downward during 
the first quarter of 2020 coupled with a decrease in government revenues from taxes and nontaxes, while government spending increased for pandemic mitigation.

\section{Determinan YIELD Curve}

The first step to be carried out is to test the stationarity of the data using the Augmented Dickey Fuller Test (ADF-Test) with a significance level $\square=10$ percent. If the t-ADF value $<$ MacKinnon critical value is $-2,929734$ and smaller than the level of significance, it can be concluded that the data do not contain unit roots or have been stationary. Data that is not stationary at level will be fermented at level 1 (first difference). The test results can be seen in Table 2 below:

Table 2. Augmented Dickey Fuller Test Results

\begin{tabular}{lcccccc}
\hline Variable & ADF & $\begin{array}{c}\mathrm{D}(0) \\
\text { Critical } \\
\text { Value }\end{array}$ & Stationary & ADF & $\begin{array}{c}\mathrm{D}(1) \\
\text { Critical } \\
\text { Value }\end{array}$ & Stationary \\
\hline YIELD & -2.107 .265 & 0,2426 & No & -7.429 .421 & 0,0000 & Yes \\
CPI & -2.190358 & 0,2118 & No & --5.832288 & 0,0000 & Yes \\
GDP & 0,547695 & 0,8739 & No & -7.794639 & 0,0000 & Yes \\
BIR & -1.838 .816 & 0,3585 & No & -6.249653 & 0,0000 & Yes \\
KURS & -1.701 .195 & 0,4257 & No & -5.491 .949 & 0,0000 & Yes \\
CD & -1.406 .513 & 0,5734 & No & -7.229 .508 & 0,0000 & Yes \\
\hline
\end{tabular}

Source: Eviews Processing Results

All variables tested were not stationary at the level evidenced by a critical value greater than the significance value and the critical value of MacKinnon. Level 1 differentiation is done on all data and the results are all statistical variables at first difference. This shows that all variables have mean, variance and covariance constant. Simultaneously the ADF-Test results on all variables indicate that all stationary data at first difference (Appendix-1).

Testing will continue to estimate the VAR model, but the optimum lag will be determined beforehand to eliminate the autocorrelation problem that will be used in the stability analysis. The test is carried out using the smallest or minimum AIC, SC and HQ. Appendix-2 show that the optimum lag is at Lag 2. The stability of the VAR model must be tested using the Roots of Characteristic Polynominal, because if the results of the estimated VAR stability show unstable results then the IRF and FEVD analyzes become invalid. The VAR model is said to be stable if all the roots have a modulus $<1$. The test results show that the VAR model formed in Lag 2 has been stable (Appendix-3). Estimates of the formed VAR model can be seen in Appendix-4.

The causal relationship between variables in the research was examined using the Granger Causality Test at the optimum lag with a significance value $\alpha=10$ percent. If the probability value <significance value, it is concluded that there is a causal relationship between these variables. Relationships can be direct, two-way or no relationship. The test results can be seen in Appendix-5 and interpreted in Table 3 below.

Table 3. Granger Test Causality Results

\begin{tabular}{ccccccc}
\hline Variable & & \multicolumn{5}{c}{ Probability } \\
Probability & YIELD & CPI & GDP & BIR & ER & FER \\
\hline YIELD & & $\rightarrow$ & $\leftrightarrow$ & $\leftrightarrow$ & $\neq$ & $\rightarrow$ \\
CPI & $\neq$ & & $\neq$ & $\neq$ & $\neq$ & $\neq$ \\
GDP & $\leftrightarrow$ & $\neq$ & & $\leftrightarrow$ & $\leftrightarrow$ & $\leftrightarrow$ \\
BIR & $\leftrightarrow$ & $\neq$ & $\leftrightarrow$ & & $\neq$ & $\rightarrow$ \\
KURS & $\neq$ & $\neq$ & $\leftrightarrow$ & $\leftarrow$ & & $\neq$ \\
CD & $\neq$ & $\leftarrow$ & $\leftrightarrow$ & $\neq$ & $\leftarrow$ & \\
\hline
\end{tabular}

Description: $\leftrightarrow$ Significant two ways. $\rightarrow \leftarrow$ Significant one-way. $\neq$ Not Significant.

Source: Results of Processing Eviews in Appendix 5

Table 3 shows that there are five pairs of two ways causal relationships that are GDP and BIR, GDP and KURS as well as GDP and CD. This indicates that the movement of 
YIELD is influenced by the movement of GDP and BIR, and vice versa. On the other hand the movement of GDP is influenced by the movement of BIR, KURS and CD, the opposite also applies to these variables. These results are in line with research by Sihombing et al. (2013); Jurksas and Kropiene (2014); and Sundoro (2018) which state that these variables affect the change in YIELD. Two variables are possible to be dependent variables while other are independent.

The next step is to determine the long-term influence on the variables studied through Engle-Granger and Johansen Trace Statistic cointegration testing and determine the number of vectors ( $\mathrm{r}$ ) between the existing system variables. If the value is trace statistic > critical value, then the variable is considered to have a cointegration or long-term relationship and the research stage will be forwarded to the VECM stage. But if on the contrary, the research will proceed to the VAR stage. Appendix 6 shows the results of the cointegration test summarized in Table 4. below.

Table 4. Johansen Cointegration Test Results

\begin{tabular}{|c|c|c|c|c|c|c|c|}
\hline \multirow{3}{*}{$\begin{array}{c}\text { Hypothesized } \\
\text { No. Of } \\
\text { CE }(\mathrm{S})\end{array}$} & \multirow{3}{*}{ Eigenvalue } & \multicolumn{3}{|c|}{ Cointegration Rank Test (Trace) } & \multicolumn{3}{|c|}{$\begin{array}{l}\text { Cointegration Rank Test } \\
\text { (Maximum Eigenvalue) }\end{array}$} \\
\hline & & Trace & 00.05 & & $\begin{array}{l}\text { Max- } \\
\text { Eigen }\end{array}$ & 00.05 & \\
\hline & & Statistic & $\begin{array}{l}\text { Critical } \\
\text { Value }\end{array}$ & Prob ** & Statistic & $\begin{array}{l}\text { Critical } \\
\text { Value }\end{array}$ & Prob.** \\
\hline None * & 0,539215 & 1,299930 & 9,901521 & 0,0003 & 4,571455 & 3,815587 & 0,0135 \\
\hline At most $1 *$ & 0,419788 & 8,427840 & 7,277447 & 0,0124 & 3,211731 & 3,216525 & 0,1012 \\
\hline At most $2 *$ & 0,324543 & 5,216109 & 5,052532 & 0,0734 & 2,314959 & 2,612122 & 0,2121 \\
\hline At most 3 & 0,266133 & 2,901150 & 3,226837 & 0,1990 & 1,825621 & 2,005014 & 0,1671 \\
\hline At most 4 & 0,095418 & 1,075530 & 1,798038 & 0,5658 & 5,916677 & 1,390590 & 0,7972 \\
\hline At most 5 & 0,078738 & 4,838621 & 7,556722 & 0,3016 & 4,838621 & 7,556722 & 0,3016 \\
\hline
\end{tabular}

Explanation : Significant at $\alpha=10 \%$ and Lag 2

Source: Results of Processing Eviews in Appendix-6

From Table 4 the test results show that there are two stationary cointegration or linear combinations between the six research variables (Appendix-6). It is interpreted that all variables movement are adjusting each other in the short run to achieve balance in the long run. Based on the conclusion above, the estimation of the form of the VECM equation can be done.

In VECM modeling, the longrun and shortrun relationships of each independent variable to dependent variables will be analyzed. If the value of $t_{\text {-count }}>t$-table $(t$-table $=1,67)$ so we can see a long-term relationship between these variables. The test results can be seen in Appendix-7 while the coefficients of the VECM model in the YIELD curve equation can be seen in Table 5 below.

Table 5. Long-term Johansen Cointegration Test Results

\begin{tabular}{ccc}
\hline Variable & Cointegration Equation 1 (CE 1) & Cointegration Equation 2 (CE 2) \\
\hline D(YIELD $(-1))$ & 1.000 .000 & 0,000000 \\
D(CPI(-1)) & 0,000000 & 1.000 .000 \\
D(GDP(-1)) & 0,045096 & $-0,558763$ \\
D(BIR(-1)) & $-0,763469^{*}$ & $-1.020 .790^{*}$ \\
D(LOG(KURS(-1)) & $9,827846^{*}$ & -6.820 .054 \\
D(CD (-1)) & $0,106672^{*}$ & $-0,171818^{*}$ \\
C & $-0,066307$ & 0,063161 \\
\hline
\end{tabular}

Explanation: * is hypothesis 0 rejected at $10 \%$ significance

Source: Results of Processing Eviews in Appendix-7

The equation coefficient as seen in Table 5 shows the positive or negative influence of a variable on other variables in the long run. $\mathrm{CD}$ has a significant positive effect on YIELD, if CD rises by one unit, it will increase YIELD by 0,1 unit. This result is in line with Gandhi (2006) which states that if a country uses its foreign exchange reserves to increase its capability, then that country will choose to invest in other securities instruments. The policy will decrease 
country's liquidity, thereby decrising bond prices and upsizing YIELD. The results of this research are proven by the Indonesia government's actions to buy SUN on a large scale starting in April 2020 to increase bond prices on the market. Even though the government's foreign exchange reserves have increased, their liquidity will decrease so investors read this as an increase in liquidity risk and increase YIELD SUN.

In addition, longrun relationship between YIELD and BIR are significant negative, if BIR increases in one unit so YIELD will reduce in 0,76 unit. These results contradict Jurksas and Kropiene (2014); Gadanecz et al. (2014) but are in line with research by Ichsan et al. (2013). Bond price movements tend to be slow when compared to stocks so that they are often used as hedging instruments. BIR acts as a projector of bond price movements, so the relationship between YIELD and BIR will eventually experience a new balance. In the shortrun, rising BIR will reduce bond prices because investors prefer to invest in short-term instruments such as money market funds. But in the long run,

The exchange rate of the rupiah against the dollar has a significant positive relationship with YIELD. If KURS rises in one unit so YIELD will increase by 9,83 units. Jurksas and Kropiene (2014) and Gadanecz et al. (2014); Ichsan et al. (2013); Sihombing (2013); and Sundoro (2018) founded the same result. The composition of foreign and domestic investor bond ownership in SBN shows the magnitude of the effect of the exchange rate on yield. IPBA recorded an increase of foreign ownership in SUN for about $+25,51$ percent yoy (in 2017) and $+6,92$ percent yoy or Rp. 893,43 trillion (in 2018). If the rupiah depreciates, foreign investors will choose to take a sell-off SUN that can reduce its prices. On the other hand the government will increase yields in the long run to attract investors.

VECM estimation is said tobe valid if probablity result of Residual Portmanteu Test $>\alpha=$ 10 percent (Appendix-7). Short run movement of YIELD in VECM estimaton can be seen in Appendix-8 and summarized in Table 6.

Table 6. Short-Term Johansen Cointegration Test Results

\begin{tabular}{|c|c|c|c|c|c|c|}
\hline Koreksi Galat & $\begin{array}{l}\text { D(YIELD, } \\
2)\end{array}$ & $\mathrm{D}(\mathrm{CPI}, 2)$ & $\mathrm{D}(\mathrm{GDP}, 2)$ & $\mathrm{D}(\mathrm{BIR}, 2)$ & $\begin{array}{c}\mathrm{D}(\mathrm{LOG}(\mathrm{K} \\
\mathrm{URS}), 2)\end{array}$ & $\mathrm{D}(\mathrm{CD}, 2)$ \\
\hline CointEq1 & $-0,360722$ & $-0,174247$ & 0,286654 & $0,329873 *$ & $-5,32 \mathrm{E}-05$ & $-1.280 .549 *$ \\
\hline CointEq2 & $-0,099550$ & $-0,688127 *$ & $-0,087828$ & 0,079211 & $-0,005582$ & $6.008 .650 *$ \\
\hline $\mathrm{D}(\mathrm{YIELD}(-1), 2)$ & $-0,588727 *$ & 0,043550 & $-0,338342 *$ & $-0,250549^{*}$ & 0,008641 & $5.693 .334 *$ \\
\hline $\mathrm{D}(\mathrm{YIELD}(-2), 2)$ & $-0,282271^{*}$ & $-0,063045$ & $-0,290947 *$ & $-0,307095 *$ & 0,001205 & 0,615490 \\
\hline $\mathrm{D}(\mathrm{CPI}(-1), 2)$ & 0,044904 & $-0,044967$ & $-0,024713$ & $-0,103486$ & $-0,006668$ & -1.753 .700 \\
\hline $\mathrm{D}(\mathrm{CPI}(-2), 2)$ & 0,070556 & $-0,011709$ & 0,057240 & 0,036023 & $-0,003675$ & -1.089 .222 \\
\hline $\mathrm{D}(\operatorname{GDP}(-1), 2)$ & $-0,195738$ & $-0,504965^{*}$ & $-0,915440 *$ & 0,111572 & $-0,010907$ & 2.940 .938 \\
\hline $\mathrm{D}(\operatorname{GDP}(-2), 2)$ & $-0,688306^{*}$ & $-0,259644$ & $-0,725826 *$ & 0,204311 & $-0,050574 *$ & $6.308 .715^{*}$ \\
\hline $\mathrm{D}(\mathrm{BIR}(-1), 2)$ & $-0,322146$ & $-0,446899^{*}$ & 0,071084 & $-0,386092 *$ & $-0,012472$ & 1.394 .811 \\
\hline $\mathrm{D}(\mathrm{BIR}(-2), 2)$ & $-0,464730 *$ & $-0,227647$ & 0,045855 & $-0,305689^{*}$ & $-0,018585^{*}$ & 2.728 .319 \\
\hline $\mathrm{D}(\operatorname{LOG}(\operatorname{KURS}(-1)), 2)$ & 3.556 .145 & 6.110 .499 & -1.327 .672 & $-0,564121$ & $-0,728635^{*}$ & $1.410 .624 *$ \\
\hline $\mathrm{D}(\operatorname{LOG}(\operatorname{KURS}(-2)), 2)$ & -2.853 .969 & $1.160 .764 *$ & 1.327 .560 & 3.788 .544 & $-0,422361 *$ & $1.069 .932 *$ \\
\hline $\mathrm{D}(\mathrm{CD}(-1), 2)$ & 0,012893 & $-0,067717 *$ & $-0,053380 *$ & $-0,014766$ & $-0,000984$ & $0,645656^{*}$ \\
\hline $\mathrm{D}(\mathrm{CD}(-2), 2)$ & 0,005748 & $-0,032352 *$ & $-0,018229 *$ & $-0,006145$ & $-0,000624$ & 0,160954 \\
\hline
\end{tabular}

Explanation: * is hypothesis 0 rejected at 10 percent significance

Source: Results of Processing Eviews in Appendix-7

Table 6 shows that the current YIELD is significantly negative due to changes the past 1 month and 2 month of YIELD periods. If the past yields decrease in one unit so the current YIELD will increase by 0,588727 units and 0,282271 units. Yield expectation theory states that long run yield reflected by the expected return on short-run yields in the future. Sihombing (2012) writes about bond yield theory, according to Martelli, an increase or decrease in yields is an increase or decrease in the short-term interest rate. Bond yield theory said an increase or decrease in yields is an increase or decrease in the short-term interest rate Sihombing (2012). High maturity will increase default risk, especially amid an uncertain pandemic situation so maturity bonds will adjust its yield to balance the curve. The results are in line with the liquidity 
preference theory which states that the rate of return is a reflection of the amount of current and short-term interest rates coupled with the risk premium borne.

YIELD in the short term was also affected by the decline in GDP and BIR two months ago. If short-run BIR rise by one unit, bond yields will decrease by $-0,464730$ units. BIR variable has a significant negative effect on YIELD in the long and short run. This is in line with research by Budina and Mantchev (2000); Batten et al. (2006); Sihombing et al. (2012); Jurksas and Kropiene (2014); and Gadanecz et al. (2014) which show that long-term bonds are less responsive to increases in BIR compared to short-term, resulting in a large gap between the two. For conservative investors, short-term bonds are the best alternative investment for now compared to other instruments. A higher return than BIR offered with a lower risk of shares is an attractive solution. But pandemic conditions make investors more careful in investing, so that the volume of bond transactions is in a limited range. The government took action to increase the price of bonds, thereby reducing the amount of YIELD provided.

Whereas the decline in GDP two months ago significantly affected the current YIELD increase of 0,69 units. The corona pandemic has reduced Indonesia's economic growth in the past two months, so that government revenue from GDP has been impacted. If the BIR is lowered as an expansionary monetary policy, then bonds are an attractive alternative to public funds. SUN yields are raised as an attractive factor for investors to invest in bonds so that the government is able to cover its deficit through the sale of this instrument. If the BI interest rate is lowered as an expansionary monetary policy, then bonds are an attractive alternative to public funds. SUN yields are raised as an attractive factor for investors to invest in bonds so that the government is able to cover its deficit through the sale of this instrument.

The real ECT coefficients in influencing the YIELD of government bonds are CPI, BIR and $\mathrm{CD}$, meaning that these variables are very important in determining the yield of the long term. The speed of adjustment in the direction of long-run equilibrium occurs in CPI, BIR and $\mathrm{CD}$, but the BIR is faster in adjusting towards the long-run balance compared to other variables with an ECT coefficient of 0,33 . The estimation results show that the average R-squared is above 55 percent with the highest value of 79,35 percent, this indicates that the equation was formed because the research variables amounted to the R-squared results.

\section{The Impact of the Pandemic on the Yield Curve}

This research tracks current and future responses to shocks using Impulse Respone Functions (IRF) provided by VAR / VECM analysis over the next 50 months. Appendix-9 shows 36 images of changes or shock of each variable due to an increase or decrease in one standard deviation of a variable after the corona pandemic. YIELD, CPI and KURS shocks will cause a decrease in YIELD in the short term, on the other hand GDP, BIR and FER will increase YIELD as illustrated in Figure 3. Within 12 months, the YIELD variable was very volatile due to the shock of the spread of the corona virus, but the balance would be achieved after the $24^{\text {th }}$ period. During that period the possibility of a corona vaccine was discovered and distributed throughout the world, so that economic activity could be recovered. 

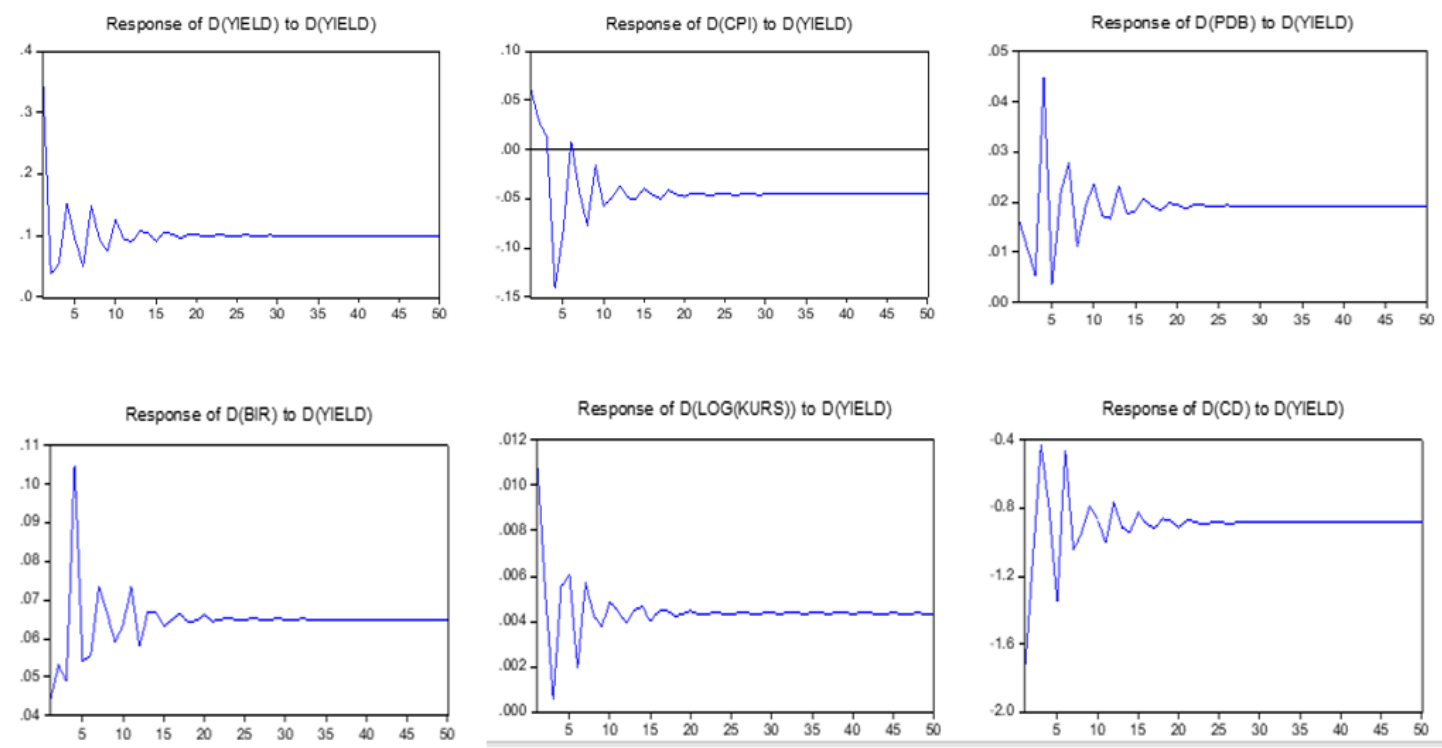

Figure 3. Response of All Variables to D (YIELD)

Source: IRF Results with Eviews Processing in Appendix-9

Quarantine and social distancing carried out as a mitigation of the spread of the virus have resulted in reduced economic activity that reflected by decreasing three macro economic indicators. The decline in the CPI is an indication of a decline in consumption spending that has resulted in a slowdown in economic growth (GDP) as an excess of enforcement of the regulation. This has encouraged investors to prefer to make investments that are safe heaven such as government bonds compared to other instruments such as stocks. Purchasing activities will increase bond prices and reduce YIELD in the short term. But in the long run, economic recovery by the government will increase inflation which marks an increase in economic activity. Bond prices will be distorted, especially high tenor bonds and investors will begin to release bonds. An increase in YIELD will be demanded by investors as a risk compensation that must be borne. This is consistent with the Bond Interest Rate Theory and is in line with Sihombing (2013); Baldacci (2008); Sundoro (2018); and Ichsan (2013) research.

The government has implemented the BI rate cut as a step to curb inflation and increase people's purchasing power. In theory, this will be responded by the market by buying bonds in the short term, which will impact on the decline in YIELD. However, at present the community has not been able to invest due to the number of layoffs and the reduction in economic activities. The government uses its foreign exchange reserves to absorb bonds released in the market as an effort to increase prices. This action will reduce government liquidity and have an impact on increasing default risk and liquidity risk. These two factors will actually reduce the price of bonds and increase yields. In the long term, easing monetary policy will increase economic growth and investor expectations of investment. Bond purchases will increase prices and reduce the YIELD provided. This response is in line with research conducted by Gandhi (2006); Muharam (2011); Baldacci et al. (2008); Budina and Mantchev (2000); and Sundoro (2018). The spread of the corona virus also caused shocks to the exchange rate of the rupiah against the dollar. This will automatically affect CD because of the link between the balance of payments and the exchange rate. On the other hand, the weakening of the domestic currency is the impact of investors' fears of massive dollar purchases. This causes an increase in prices of goods and services, especially those based on imports and will trigger inflation. This signal is read by investors as uncertainty and risk in investing, especially in the long run. Short-term investment instruments are safer options such as low-tenure government bonds. An increase in purchases will increase the price of bonds and reduce the YIELD provided. Some studies that support this result are Wibisono (2010); Jaramillo and Weber (2012); and Sihombing et al. (2013). 


\section{Yield Curve Forecasting}

The Forecasting Variant Decompositon (FVED) test was carried out to see the contribution of each variable in the long run for 50 months. Appendix-10 contains the test results, the average contribution of each variable to other variables is summarized in Table 7.

Tabel 7. Forecasting Varian Decomposition

\begin{tabular}{lcccccc}
\multicolumn{1}{c}{ VARIABEL } & D(YIELD) & D(CPI) & D(GDP) & D(BIR) & D(LOG(KURS)) & D(CD) \\
\hline D(YIELD) & $66,79 \%$ & $2,83 \%$ & $8,57 \%$ & $5,61 \%$ & $4,88 \%$ & $6,42 \%$ \\
D(CPI) & $5,92 \%$ & $36,04 \%$ & $3,33 \%$ & $27,73 \%$ & $15,98 \%$ & $17,92 \%$ \\
D(GDP) & $2,39 \%$ & $1,19 \%$ & $81,26 \%$ & $1,71 \%$ & $2,91 \%$ & $11,13 \%$ \\
D(BIR) & $29,65 \%$ & $6,17 \%$ & $9,79 \%$ & $47,43 \%$ & $7,54 \%$ & $3,50 \%$ \\
D(LOG(KURS)) & $31,38 \%$ & $2,67 \%$ & $14,40 \%$ & $2,79 \%$ & $40,44 \%$ & $9,89 \%$ \\
D(CD) & $28,39 \%$ & $3,89 \%$ & $8,21 \%$ & $5,07 \%$ & $1,29 \%$ & $47,25 \%$ \\
\hline
\end{tabular}

Source: FVED Results with Processing Eviews in Appendix-10.

From the table above it can be seen that the YIELD variable in the long run is influenced by itself as much as 66,79 percent, the rest is influenced by GDP, CD, BIR, KURS, CPI and other factors. While the CPI behavior is influenced by itself by 36,04 percent and BIR by 27,73 percent and the rest are other variables with proportions as shown in the table. The movement of GDP is more influenced by itself in the amount of 81,26 percent and CD at 11,13 percent while other variables only affect below 3 percent. In accordance with the monetary policy adopted by the government, the KURS variable is influenced by YIELD and itself by 31,38 percent and 40,44 percent. While the behavior of foreign exchange reserves is influenced by YIELD and CD by 28,39 percent and 47,25 percent.

\section{Managerial Implications}

Corona pandemic has caused economic shock due to quarantine and social distancing. Declining economic activity has reduced the source of government revenue from various sectors, especially tax and service sectors. On the other hand, the government is demanded to increase the degree of health and the cost of overcoming the spread of the virus. This counter productive situation will increase the deficit of government expenditure. The reduction in Bank Indonesia interest rates is an expansionary monetary step to increase public consumption which is expected to increase government revenue. However, the lack of people's purchasing power due to layoffs and the reduction in production activities has made the government look for other alternatives by issuing even global bonds. This action will increase the government revenue balance, but on the other hand will also add to the burden of expenditure for payment of yields.

The government needs to be aware of this especially if the rupiah exchange rate continues to depreciate. Government intervention on the exchange rate of the rupiah against the dollar in the spot and forward markets through Domestic Non-delivery Forward must be limited so as not to distort foreign exchange reserves too deeply. In addition, the use of foreign exchange reserves to absorb bonds in the market also needs to be calculated carefully so that liquidity can be controlled, especially the results of research prove that the new balance will be achieved after 24 months. This long period of time will be achieved if the corona vaccine has been found and distributed as a whole. If the pandemic period grows longer and the move continues as a longterm monetary policy, investors will see this action as the government's inability to manage its liquidity and will demand increased yields as compensation. The increase in yield will affect the yield curve and bond prices, the impact is to lower the rating of government bonds and investor expectations.

Research has proven that in the short run, decreasing all variables will reduce bond prices and increase yields. This is a buying signal for investors to increase their portfolio with SUN. Government bonds are one of the safe heaven investments at this time, although some investors view government actions to buy bonds in the market as an increase in liquidity risk. Anticipatory steps can be taken is to choose short or medium term bonds that provide the highest yields at an undervalued price. In addition, investors can diversify their portfolios by buying gold and money market mutual funds as investment instruments that are quite safe at this 
time. Long-term bond purchases should be avoided because economic recovery after the discovery of vaccines will increase inflation and economic growth. This marked an increase in economic activity and investor expectations of investment that have implications for rising bond prices and lower yields.

\section{CONCLUSION}

Descriptive analysis proves that the economic impact at the beginning of a pandemic is a decrease in inflation, economic growth and interest rates at the same time. On the other hand this condition increases the country's exchange rate and foreign exchange reserves. This research proves that the five main macroeconomic indicators have an influence in the short and long term on the yield curve. YIELD, GDP and BIR variables have a significant negative effect in the short term on the yield curve, whereas CPI, KURS and CD have no significant effect. The Bond Interest Rate theory explains that current yields will be influenced by short-term bond interest rates plus the risk premium that must be borne by investors. The decline in GDP will increase investor concerns about the increased risk of bonds so that investors, especially foreigners, take action to reduce the price of bonds. This will increase the yield given as compensation and attract investors to want to invest. The results of the analysis have answered research questions about the impact of the pandemic on yields in the short run.

In the long run, the yields are significantly positively influenced by KURS and Foreign Exchange Reserves. Increasing each of these variables by one unit will increase YIELD by 9,83 and 0,1 units. An increase in the number of foreign investors in Indonesian government bonds will have a domino effect on yield. The depreciation of the rupiah will cause investors to move their investments in short-term instruments other than bonds which will impact on price reductions and increase the requested yields. The government took anticipatory action by buying SUN on a large scale starting in April 2020 to increase bond prices on the market. However, the use of foreign exchange reserves owned by the state to buy this instrument is read mainly by foreign investors as a threat to liquidity.

The ECT's coefficient shows the speed of adjustment towards the long-term balance and the BI Rate adjustment is faster than other variables with an ECT coefficient of 0,33. The estimation results show that the average R-squared is above 55 percent with the highest value of 79,35 percent, this indicates that the equation was formed because the research variables amounted to the R-squared results.

This situation also caused shock to the independent variables of the research that influenced the dependent variable of the research, namely YIELD, especially in the short term. The balance of all variables will be achieved after the $24^{\text {th }}$ period of the research, which means 2 years after March 2020. CPI shocks will be responded to by decreasing yields, because investors prefer to make investments that are safe heaven. This will trigger an increase in bond prices and a decline in YIELD. While the shock on the BIR will be responded by an increase in YIELD due to the lack of investor purchasing power of bonds which causes a decrease in bond prices. Rupiah depreciation is a shock to the exchange rate which will automatically affect foreign exchange reserves due to the connection with the balance of payments. This signal is read by investors as uncertainty and risk in investing, especially in the long term so that shortterm investment instruments are a safer choice. The research found that in the long run YIELD is predicted to be influenced by itself as much as 66,79 percent, the rest is influenced by other variables.

\section{Suggestion}

Research data is still limited until March 2020, which means the pandemic has only been government in dealing with this pandemic helped to worsen economic conditions. There are no indications of providing adequate vaccines and health facilities to make the situation worse, so that the shock felt is greater. The results of the research will be more accurate if the research 
term period is extended and dummy administration is in the form of an increase in the number of corona sufferers in the research.

\section{REFERENCES}

Che-Yahya, N., Abdul-Rahim, R., \& Mohd-Rashid, R. (2016). Determinants of Corporate Bond Yield: Case of Malaysian Bond Market. International Journal of Business and Society, 17(2), 245-258.

Chen, T. K., Liao, H. H., \& Tsai, L. P. (2010). Internal Liquidity Risk in Corporate Bond Yield Spreads. Journal of Banking and Finance, 35(4), 978-98.

Rahardjo, S. (2004). Panduan Investasi Reksadana. Jakarta: PT. Gramedia.

Sihombing, P., Siregar, H., Manurung, A. H., \& Santosa, P. W. (2013). Determinant Yield Curve Surat Utang Negara. Finance and Banking Journal, 15(1), 68 - 89.

Jaramillo, L., \& Weber, A. (2012). Bond Yields in Emerging Economies: It Matters What State You Are In. IMF. IMF Working Paper, 12, 198.

Sundoro, H. S. (2018). Pengaruh Faktor Makro Ekonomi, Faktor Likuiditas Dan Faktor Eksternal Terhadap Yield Obligasi Pemerintah Indonesia. Journal Of Business \& Applied Management, 11(1), 102-115.

Orlowski, L. T., \& Kirsten, L. (2005). Bond Yield Compression in the Countries Converging to the Euro. William Davidson Institute Working, 799.

Rahman, Anang, A., \& Sam'ani. (2013). Analisis Faktor-faktor yang Mempengaruhi Yield Obligasi Negara Tahun 2010-2012. Jurnal Ekonomi-Manajemen-Akuntansi, 20(35), 1-16.

Hsing, Y. (2015). Determinants of the Government Bond Yield in Spain: A Loanable Funds Model. International Journal of Financial Studies.

Muharam, H. (2011). Model Determinan Imbal Hasil Obligasi Pemerintah. Semarang: Disertasi Universitas Diponegoro.

Perovic, L. M. (2015). The Impact of Fiscal Positions on Government Bond Yields in CEE Countries. Journal of Economic System, 39(2), 301-316.

Gadanecz, B., Ken, M., \& Chang, S. (2014). Exchange Rate Risk and Local Currency Sovereign Bond Yields in Emerging Market. BIS Working Paper, 474.

Wibisono, R. (2010). Pengaruh Variabel Makroekonomi dan Kecepatan Penyesuaian Keseimbangan dalam Memilih Obligasi Pemerintah Berdasarkan Tenor. Jakarta: Skripsi Universitas Indonesia.

Bodie, Z., Alex K., \& Alan, J. M. (2006). Investasi Buku 2. Jakarta: Penerbit Salemba Empat.

Mateev, M., \& Videv, A. (2008). Multifactor asset pricing model and stock market in transition: New empirical tests. Eastern Economic Journal, 34, 223-237.

Ichsan et al. (2013). Dampak BI Rate, Tingkat Suku Bunga, Nilai Tukar, dan Inflasi terhadap Nilai Obligasi Pemerintah. Jurnal Keuangan dan Perbankan, 17(2), 310-322.

Jurksas, L., \& Kropiene, R. (2014). Macroeconomics determinants of Lithuanian government security prices. Ekonomika, 93(4).

Budina, N., \& Mantchev, T. (2000) Determinants of bulgarian brady bond prices: an empirical assessment. World Bank Policy Research Working Paper, 2277, 1-30.

Baldacci, E., Gupta, S., \& Mati, A. (2008). Is it (still) mostly fiscal? Determinants of sovereign spreads in emerging markets. IMF Working Paper, 8(259), 1-23.

Idham, A. (2014). Analisis Faktor Determinan yang Mempengaruhi Yield Obligasi (Studi Empiris Pemerintah Indonesia 2009:1-2013:12). Yogyakarta: Skripsi Universitas Gajah Mada

Rose, S. A., et al. (2010). Fundamental of Corporate Finance. (9th Edition). New York: McGraw-Hill

Fabozzi, F. J. (2000). Bond Market, Analysis and Strategies. Prentice-Hall, Inc, 4th edition.

Tandelilin, E. (2010). Portofolio dan Investasi, Teori dan Aplikasi, Edisi Pertama. Yogyakarta: Kanisius 
Miyajima, K., Mohanty, M.S., \& Chan, T. (2012). Emerging market local currency bonds: diversification and stability. BIS Working Papers, 391.

Diebold, F. X., \& Li, C. (2006). Forecasting the term structure of government bond yields. Journal of Econometrics, 130, 337-364.

Widarjono, A. (2013). Ekonometrika: Pengantar dan aplikasinya. Jakarta: Ekonosia.

Verbeek, M. (2000). A Guide to Modern Econometrics. West Sussex: John Wiley \& Sons.

Gandhi, D. V. (2006). Pengelolaan cadangan devisa di Bank Indonesia. Jakarta: Pusat Pendidikan dan Studi Kebanksentralan (PPSK) BI.

Sihombing, P., Siregar, H., Manurun, A. H., \& Santosa, P. W. (2012). Analisis Pengaruh Makro Ekonomi Terhadap Term Structure Interest Rate Obligasi Pemerintah (Sun) Indonesia. International Journal of Information Technology and Business Management, 25(1), 2237. 